\title{
International Financial Transactions and Corporate Performance in a Dynamic Financial Market (Evidence from Nigerian Financial Sector)
}

\author{
Suoye Igoni, Akpeghughu, Mevrabor Kingsley \\ Department of Finance and Banking, University of Port Harcourt, Port-Harcourt, Nigeria
}

Email address:

uchechukwunwachukwu@yahoo.com (Akpeghughu)

\section{To cite this article:}

Suoye Igoni, Akpeghughu, Mevrabor Kingsley. International Financial Transactions and Corporate Performance in a Dynamic Financial Market (Evidence from Nigerian Financial Sector). International Journal of Finance and Banking Research.

Vol. 3, No. 1, 2017, pp. 13-21. doi: 10.11648/j.ijfbr.20170301.12

Received: December 14, 2016; Accepted: January 12, 2017; Published: March 21, 2017

\begin{abstract}
The primary aim of this study is to examine the relations between international financial transactions and corporate performance in a dynamic financial market within the banking industries using Annual Time Series Data of the Variables. The annual time series data were sourced majorly from central bank of Nigeria statistical bulletin. This study covers 33 years period between 1980-2013. Econometric techniques of ordinary least square (OLS) Augmented were employed in the analysis. Return on investment was used as a measure of corporate performance. The international financial transactions measure includes (growth of cross-border credits to total deposit money banks assets, growth of non oil export to deposit money bank asset, cross border banking claims to total deposit money bank assets and exchange rate) as independent variables. The results indicate that corporate performance in a financial market which is measured by return on Investment has a positive and significant relationship on growth of cross boarder credit to total deposit money banks assets, growth of non-oil export to deposit money banks assets, cross boarder banking claims to total deposit money bank assets and ratio of exchange rate of Naira to Dollar. Consequently, it is recommended that there is every need for the deposit money banks management to strengthen their international financial transactions management scope as the indicators studied largely exhibit strong influence on the performance of deposit money banks.
\end{abstract}

Keywords: Corporate Performance, International Financial Transaction, Non-oil Export, Cross Boarder Banking Claims

\section{Introduction}

The corporate performance in international financial transactions over the years has remained puzzled especially as a result of global financial crises. This is because the performance of financial market of the emerging economies like Nigeria has received an increasing attention by researchers in the last decades after the global financial crisis between 2007 and 2008 that affected negatively cross boarder capital flows. For instance, the price of Bonny Light Crude Oil Spot stood at $\$ 95.16$ per barrel within January 2008 and now rose to $\$ 146.15$ in July the same year before declining to $\$ 76.24$ per barrel by October 17,2008 . It recorded lost of fifty percent of its highest price within four months. These as a result of the fall in the universal cost of oil which prompted to serious decrease in remote trade receipts and thusly government income compression.

Global monetary environment is considered too harsh for effective and efficient management of Nigerian foreign assets for the betterment of Nigerian financial market, for instance the world monetary crisis of 1971 which led to the devaluation of Nigerian currency in 1973, affected the Nigeria banking industry. The global liquidity crisis shows how financial market can easily be broadcasted in a unified world. For this reason, the global gross capital inflows fell from twenty percent of gross domestic products at their peak in 2007 to over one percent in 2009 and total stock of gross boarder banking claims fell by third from fifty-two percent of overall GDP in 2007 to thirty-eight percent in 2012 (McClean and Shrestha, 2009). Therefore, banking system is much larger than they use to be and have greater exposure to global monetary shocks. 
International financial transaction is grouped under international liquidity as private financial intermediaries such as the banking institutions and the official entities such as the Central Banks (Halland and Vierra, 2005). Conceptually, financial transactions across borders capture the overall ease of financing prevalent in the world economy. It is a vehicle for the numerous interactions and spill over between domestic monetary policy and financial policy.

Domestically, international financial transactions entail inflow of foreign capital and policies for effective utilization of a country's foreign assets to enhance financial stability and achieve prudential regulations towards the achievement of desired macroeconomic.

(Brown and Haas, 2012). However, the international financial environment can affect negatively the performance of the financial sector. For instance the Nigeria capital market crash that led to the banking sector crisis in 2007/2008 was traced to the global financial crisis (Jiwan, 2011).

Nigeria government has embarked on financial sector reforms and integrates the financial institutions to global financial corporations for effective management of Nigerian foreign assets. For instance, 14 Nigerian Deposit Money Banks were selected after the consolidation reforms to manage Nigeria's external reserve. The extent to which these policies impact on the performance of Deposit Money Banks through the international financial transactions process remained a knowledge gap. Much of the research on international financial transactions and performance of deposit money banks of the emerging financial markets is recent with still many conceptual and empirical gaps. In order to consider the effect of the various dimensions of international financial transactions on the performance Nigerian banking sector, the common measures are documented with respect to private and official liquidity.

Many literatures on international financial transactions and corporate performance in dynamic financial market can hinder the corporate profitability of deposit money banks in emerging financial markets like Nigeria, in other words, these studies have failed to capture variables in international financial transaction that impact on the performance of the banking industry directly.

Research Hypothesis

In view of the problems identified, the following null hypotheses are formulated in the study.

$\mathrm{H}_{01}$ : There is no statistically significant relationship between credit growth across countries and Return on Investment of Deposit Money Banks in Nigeria.

$\mathrm{H}_{02}$ : There is no statistically significant relationship between growth of international trade and the Return on Investment of deposit money banks.

$\mathrm{H}_{03}$ : There is no statistically significant relationship between cross-boarder banking claims and the Return on Investment of Deposit money banks in Nigeria.

$\mathrm{H}_{04}$ : There is no statistically significant relationship between exchange rate and the Return on Investment of deposit money banks in Nigeria.

\section{Review of Related Literatures}

\subsection{Conceptual and Theoretical Issues}

The concept of International financial Transaction is a multifarious and complex phenomenon which steadily is organized as only clarification of monetary developments. According to BCBS 2010, there are number of developments which include: rising in stock market, commodity rising prices, decrease in bond yields and booms in real estates, increase in monetary system globally and aggregate credit. There are also fluctuations on both the price and its output. The world financial crisis affected the international financial transaction, to the extent that certain regions and markets, risk her finances which would have been use for selfsustenance.

There are many perceptible meaning of liquidity as regards to International financial Transaction and the most importantly for policy making are as follow:

Liquidity in Monetary terms is defined as the easiest way of convertibility of financial assets into goods and services.

The liquidity in the financial market, which can be refer as the easiest way by which huge quantity of monetary securities can be sold or bought without hindering the market price. Consequently, in the area of stability in finances, the idea of official liquidity consists of the apex banks fund together with private liquidity and foreign reserves.

It is important to know how International financial Transaction hinders the developments price through the impact on the international asset and commodity prices. From the perspective of the monetary policy, the important of International financial Transaction initiated from the main impact on price consumer inflation over the medium-term. As a whole, the important liquidity aspect is the ease at which the instrument exchanged for goods and services, provided it is transactions motive. That is to suggest that money play an important role and useful liquidity benchmark. BCBS, 2009 opined that overnight deposits and currency is an asset that has highest degree of liquidity. This is because money is generally acceptable as a medium of exchange for goods and services.

Theoretically, there exist positive relations within the remote inflow of foreign direct investment portfolio as well as stock market in Nigeria. This inflow of FDI into the Nigerian economy builds the measure of assets in the economy. The more significant inflow drives down financing costs and makes it simple for firms to obtain advances to set up new organizations or grow a current line of business which at last improves their productivity. There is a positive over flow impact on the share trading system if the market is proficient. The values of organizations /firms set up by the parent organization in the nation of origin may likewise be recorded on stock trade, and this could support the volume, estimation of securities exchange, advertise capitalization, showcase liquidity, and soon. Fundamentally, international.

Portfolio within the economy could not only position the multinational organizations but must have innovative ability which will enhance the company securities and inspire their 
dynamic cooperation in the market.

Foreign assistance as well as individual settlements could likewise have beneficial outcome on the improvement of the stock. In spite of the fact that the impact of the previous is not feasible, the impact of the last rely on a few components ranging from profits, instrument of monetary policy, perception of the market by the investors, financial assets, return on equity capital and soon.

Public external debt is another form of foreign financial resource that could affect the development to the stock market. A principal mechanism through which it affects the development of the market is through its effect on corporate borrowing costs, particularly in emerging market economies.

Non-oil exports are agricultural products such as coal, timber; groundnut, palm-oil, palm kernel etc are manufactured within the country in order to generate revenue for growth of the economy. This non-oil export sector in Nigeria constitutes products of agriculture, industry and services that are exported by Nigeria. On the other hand, it was noticed that deposit money banks charged high interest rate in extending credits to non-oil exports there by reduces the revenue accruing from this products to the government. With the decrease in crude oil price in international oil market, the revenue accruing to the government has drastically reduced, indicating the diversification of the economy from crude oil to non-oil exports.

That is why; economists opined that non-oil exports need little or no alternately to be desired as far as generating foreign reserve (Onwe, 2013). This demonstrates the reason that the real strategy concern the central government centered on the extension for non-oil export in order to diversity Nigeria's export base income.

Abebefe (1995) gave two consecutive reasons why Nigeria's over reliance on crude oil is hazardous. Firstly, crude oil is a depreciable asset with a proven reserve which would ultimately become exhausted and secondly, the vagaries of the oil market can result in a major decline in domestic earnings because of the external influence on the price of oil such as OPEC.

Osuntogun, Oramah and Edordu (1997), carried out analysis on the potentials for diversifying Nigeria's non-oil export to non-traditional markets. They discovered that Nigeria could not make use of her natural resources just because the implementation of export promotion policies.

\subsection{Empirical Issues on International Financial Transactions and Corporate Performance in Dynamic Financial Market}

According to Seiford and Zhu, 1999 measuring bank performance mainly the deposit money banks in different countries in the world has received a tremendous effort. Some researchers with which they used deposit money banks. Great number of studies empirically on money deposit banks performance within the globe is deployed (Webb, 2003; Yeh, 1996; Halkos and Salamouris, 2004; Lacewell, 2003: Tarawneh, 2006).

Smad(2004)examined the performance of domestically incorporated deposit money bank between 1994 and 2001. Measures of financial ratios were used to examine the profitability, credit quality and performance of liquidity. These deposit banks were evaluated using Bahrain bank. The results indicates that deposit money banks wireless valuable, less liquid and were presented to greater credit hazard than the managing an account industry, in which whole sale banks are the primary segment.

Xiao (2009) investigated the performance of French banks using both quantitative and qualitative models between 2006 and 2008. He found that French banks were not quarantine but argued that French banks are closely elastic to the global financial crisis.

Stulz and Beltratti (2009) in their analysis examine the stock return of banks in different countries beginning from 2007 to 2008. They concluded that bank that has large deposits financing will have higher return during that crisis.

Tehranian, Cornett and McNutt (2009) in their analysis used US Bank to examine the Internal Corporate governance mechanism and its performance during and after financial crisis. They conclude that the highest banks are experiencing highest losses during the crises.

Dietrich and Wanzenried (2011) carried out an investigation on how characteristics of bank, macroeconomic variables and specific industries hinder profitability of Swiss deposit money banks between 1999 and 2009. They concludes that financial crisis have significant impact on profitability of banks. Developing countries are beginning to experience the global financial crises as illiquidity now dwelling in the system. As a result of the international recession spreads, the impact will be affected on financial sector asset quality, leading to the need for recapitalization of financial institutions. The problem of liquidity shows the poor regulatory framework and mismanagement of financial institutions. Strictly imposed credit markets in countries that are developing are expediently preventing the genuine division, majorly the areas that depend on finance trade and working capital.

Ashamu and Abiola (2012) using the banking industries in Nigeria investigates that global financial crises has affected the Nigerian capital market and also has affected the credit extension by the banking industry especially those quoted in the stock exchange. They indicates that, greater loan-loss provisioning, slower development rate of banks monetary record in light of the emergency, swapping scale hazard fixing of liquidity and higher provisioning prompting lower productivity among others.

According to Kitoyta 2009, despite the fact that capital market, currencies and money had important pressures by the financial crisis, they continue to operate normal, and there is stability of financial institutions in some countries without quick support from monetary authorities. Also there findings shows that crisis had small impact financial system in African sub-Sahara region. This is because in African Sub-Sahara, financial sector are not competitive, they remain weakly, and have been integrated in to the international markets.

Ree (2011) beginning in late 2007 carried out analysis on 
the impact of the global financial crisis on banking sectors. Using high level bank data provided by the bank, he found that in spite of low financial integration in Asian banks, there is significant relationship on largest bank impact on crisis. Impacts were most palpable through a loan-to-cross border funding nexus.

Sangeetha (2012) using Omani deposit money banks in his study on the effect of global financial crisis. He found that the factors influencing the performance of the banks include: management strategy and orientations. Marketing potential of banks was strong while some banks are effective in taking care of shareholders' interest by enhancement of income and operating profit. He concluded that there is no significant relationship between the effect of global financial crisis and on the deposit money banks of Omani but significant for National Bank of Oman (NBO). The study also shows that there is high rate of stability and resilience in local commercial banks.

Anouze (2007) in Gulf Region carried out an analysis on the efficiency of banks' performance. This study was carried out during and after the political crises and financial crisis. The results indicate that Islamic banks do well during the financial crisis, while Conventional banks perform well during political crisis. Again, there are no significant relations between efficiency score and bank geographical location. In addition, the outcomes affirm that vast and little size of commercial banks is more productive than the medium size. Out of the twenty four environmental elements incorporated in to the study to examine the relationship between environmental variables and bank performance; just fifteen elements are thought to be necessary in predicting the effective banks.

According to Khamis 2010, banks were not vulnerable during the crises compare their partners in developed nations regardless of shocks, there has been no systemic break down and the effect on bank profitability has been moderated.

AlNessor (2008) examined the impact of budgetary emergency from one nation to the other notwithstanding the multifaceted nature of the economy. The analyst believed that there will be a solid impact in the present time of infrastructural projects in the estate. He prescribed the most ideal approach to focus and how Arabian country's economies will deal with the issue of financial crisis, in order to avoid more shock.

Fayez, et al (2009) in Jordan, investigates the impact of financial crisis on the financial sector. They adopted total approaches of companies quoted in the Amman stock exchange. Their study indicates that Jordan economy has been influenced by worldwide money related emergency like different nations in the world.

Berger and Chista (2010) carried out an analysis on the effect bank capital before and after crisis and its capacity to survive the financial crises. They used profitability and market shares and found that adequate capital help banks during crises. In otherworld, large capital help banks to build their likelihood of survival, market share and the benefit. Others concentrated on the genuine impacts of decay in bank wellbeing or rivalry amid the monetary emergency on bank performance.
Almeida et al (2009) and Duchin et. al (2010) critically examined the impact of monetary emergency on corporate venture in its home countries. They found that there is a decline in corporate investment which is significant as a result of financial crisis.

Tarawneh (2006) in Oman, contrast the banking sector financial performance. He used five deposit money banks that have two hundred and sixty branches in Oman. The result shows that the deposit money bank with higher deposits, total capital and credits does not have better performance on profitability.

Shafique et al (2008) carried out an investigation under the Islamic banking system on impact of global financial crises. They found out that Islamic banking system has been hindered by the world economies crisis.

This study therefore examined international financial transaction on corporate performance of Nigeria deposit money banks by looking at international monetary transactions such as cross-border credits, international banking claims exchange rates.

\section{Methodology}

This study used quasi experimental research design approach for the data analysis. The data for this study are secondary data sourced from the Nigerian Stock Exchange and Central Bank of Nigeria Statistical Bulletin. The data obtained in this study shall be estimated and analyzed, following prevalent econometric procedure such as: unit root test, co-integration and error correction model.

\subsection{Model Specification}

From theories, principles and empirical findings, the model below is specified in this study. To bring the independent variables to equal value to the dependent variables, the variables are deflated using total assets of deposit money banks.

$\mathrm{ROI}=\mathrm{f}(\mathrm{GCBC} / \mathrm{TBA}, \mathrm{GNOEX} / \mathrm{TBA}, \mathrm{CBBC} / \mathrm{TBA}, \mathrm{EXR})$

It is empirically stated as:

$$
\begin{gathered}
\mathrm{ROI}=\beta_{0}+\beta_{1} \mathrm{GCBC} / \mathrm{TBA}+\beta_{2} \mathrm{GNOEX} / \mathrm{TBA}+ \\
\beta_{3} \mathrm{CBBC} / \mathrm{TBA}+\beta_{4} E X R+\mu
\end{gathered}
$$

Where

ROI $=$ Return on Investment of Nigerian Quoted Deposit Money Banks

$\mathrm{GCBC} / \mathrm{TBA}=$ Growth of cross boarder credit to total deposit money banks assets.

GNOEX/TBA = Growth of non-oil export to deposit money banks assets.

$\mathrm{CBBC} / \mathrm{TBA}=$ Cross boarder banking claims to total deposit money banks assets.

$\mathrm{EXR}=$ Naira/Dollar Exchange Rate

$\beta_{0}=$ Intercept

$\beta_{1}-\beta_{4}=$ Coefficients

$\mu=$ Error term 
Table 1. Annual Time Series Data of the Variables (1980-2013).

\begin{tabular}{|c|c|c|c|c|c|}
\hline Year & ROI & СВC/TTBA & NOE/TCBA & CBB/TCBA & EXR \\
\hline 1980 & 165.15 & 4.360 & 381.00 & 2.513 & 0.544 \\
\hline 1981 & 186.81 & 4.537 & 475.784 & 11.264 & 0.636 \\
\hline 1982 & 207.57 & 4.011 & 308.191 & 9.082 & 0.670 \\
\hline 1983 & 223.35 & 3.820 & 244.944 & 11.286 & 0.748 \\
\hline 1984 & 242.49 & 0.003 & 285.094 & 12.603 & 0.808 \\
\hline 1985 & 267.03 & 3.954 & 284.018 & 10.320 & 3.316 \\
\hline 1986 & 253.01 & 3.514 & 186.394 & 32.633 & 4.191 \\
\hline 1987 & 309.75 & 3.379 & 541.012 & 51.564 & 5.350 \\
\hline 1988 & 329.54 & 3.389 & 496.741 & 74.060 & 7.650 \\
\hline 1989 & 319.73 & 3.132 & 719.137 & 89.543 & 9.650 \\
\hline 1990 & 360.10 & 2.663 & 959.146 & 72.052 & 9.000 \\
\hline 1991 & 366.34 & 2.682 & 782.854 & 65.136 & 9.754 \\
\hline 1992 & 375.05 & 2.904 & 976.770 & 85.703 & 19.660 \\
\hline 1993 & 411.52 & 3.193 & 864.118 & 84.333 & 22.630 \\
\hline 1994 & 421.73 & 3.754 & 631.160 & 46.339 & 21.886 \\
\hline 1995 & 428.82 & 3.692 & 2361.358 & 124.799 & 81.022 \\
\hline 1996 & 413.90 & 6.598 & 2478.430 & 81.460 & 81.252 \\
\hline 1997 & 440.94 & 3.928 & 1985.894 & 76.778 & 81.649 \\
\hline 1998 & 437.11 & 3.016 & 835.178 & 70.223 & 83.807 \\
\hline 1999 & 469.00 & 3.240 & 880.379 & 86.189 & 92.342 \\
\hline 2000 & 469.70 & 3.543 & 953.146 & 86.592 & 100.801 \\
\hline 2001 & 482.76 & 3.450 & 750.678 & 110.238 & 111.701 \\
\hline 2002 & 518.13 & 3.969 & 659.850 & 130.648 & 126.257 \\
\hline 2003 & 557.92 & 4.047 & 903.747 & 116.604 & 134.037 \\
\hline 2004 & 532.23 & 4.377 & 1064.780 & 106.596 & 132.370 \\
\hline 2005 & 568.07 & 3.519 & 1106.648 & 64.580 & 130.606 \\
\hline 2006 & 532.46 & 4.383 & 719.541 & 123.685 & 128.276 \\
\hline 2007 & 735.56 & 4.899 & 557.723 & 58.465 & 125.881 \\
\hline 2008 & 662.41 & 5.085 & 637.872 & 85.993 & 121.904 \\
\hline 2009 & 641.64 & 4.446 & 529.334 & 73.024 & 150.012 \\
\hline 2010 & 718.91 & 3.770 & 664.720 & 66.834 & 150.650 \\
\hline 2011 & 759.88 & 3.828 & 545.14 & 79.975 & 156.200 \\
\hline 2012 & 758.81 & 4.117 & 724.886 & 77.873 & 155.820 \\
\hline 2013 & 845.01 & 6.281 & 790.287 & 2.513 & 158.728 \\
\hline
\end{tabular}

Source: Central Bank of Nigerian Statistical Bulletin and stock Exchange fact book

\section{Unit Root Test for Stationarity}

The variables in the model, being global liquidity variables may be non-stationary, so regression models using these variables, tends to generate spurious result; and the outcome will be biased towards finding a significant relationships among variables. To overcome this undesirable outcome, the time-series variables were subjected to test of stationarity by testing for the presence or absence of unit root using Johansen co-integration test.

Table 2. Unit Root Test Stationarity (ADF AT DIFFERENCE).

\begin{tabular}{lllllll}
\hline VARIABLES & ADFSTATISTICS & MACKINONCRITICALVALUE1\% & $\mathbf{5 \%}$ & $\mathbf{1 0 \%}$ & PROB. & ORDEROFINTEGRATION \\
\hline ROI & -6.806722 & 3.661661 & -2.960411 & -2.619160 & 0.0000 & $1(1)$ \\
CBC/TCBA & -8.038766 & 3.653730 & -2.957110 & -2.617434 & 0.0000 & $1(1)$ \\
NOE/TCBA & -5.297992 & 3.653730 & -2.957110 & -2.617434 & 0.0001 & $1(1)$ \\
CBB/TCBA & -8.656730 & 3.653730 & -2.957110 & -2.617434 & 0.0000 & $1(1)$ \\
EXR & -6.006463 & 3.653730 & -2.957110 & -2.617434 & 0.0000 & $1(1)$ \\
\hline
\end{tabular}

Source: Authors computation using E-View7.0

The above Augmented Dickey Fuller Test shows that all the variables are stationary at first difference; this means all the variables are integrated of 1(1).

\subsection{Testing for Co-integration (The Johansen Approach)}

Having established the stationarity of the study variables, we proceed to test for long run relationship using Johansen's cointegration. The study investigates the existence of equilibrium relationship among the stationary variables of the same order of integration. The outcomes are offered in the table below. 
Table 3. Results of Johansen's Co-integration.

\begin{tabular}{lllll}
\hline Hypothesized No. of CE(s) & Eigen-value & Trace Statistic & 0.05CriticalValue & Prob. \\
\hline None & 0.8478960 & 92.390000 & 69.818899 & 0.00941 \\
Atmost1 ${ }^{*}$ & 0.7818500 & 76.987011 & 47.856137 & 0.00012 \\
Atmost2* & 0.5210212 & 45.947333 & 29.797075 & 0.00000 \\
Atmost3 & 0.1022261 & 3.5580555 & 15.494712 & 0.93596 \\
Atmost4 & 0.0033467 & 0.1072599 & 3.8414661 & 0.74330 \\
\hline
\end{tabular}

Source: Authors computation using E-View7.0

The co-integration results reported in the above table reveal that there are three co-integrating equations. Thus, the null hypothesis of no co-integration is rejected. The test in sights uncover that there is co-coordinating relationship between the dependent variable and explanatory variables. Along these lines, we presume that there is a long-run relationship between corporate performance of Nigerian banks, as captured by their Return on Investment and the selected international financial transactions indicators (Credit across Countries to Total Deposit Money Banks Assets, NonOil Export to Total Deposit Money Banks Assets, Cross Boarder Banking Claim to Total Banks Assets, Exchange Rate). In any case, we concede that deviations from this relationship could happen because of changes in any of the variables in the short-run. Along these lines, the Error Correction Mechanism (ECM) was useful to address any short-run changes.

\subsection{Tests for Error Correction Model}

Table 4. Error correction model estimate.

\begin{tabular}{|c|c|c|c|c|}
\hline \multicolumn{5}{|c|}{ Dependent Variable: D(ROI) } \\
\hline \multicolumn{5}{|c|}{ Method: Least Squares } \\
\hline \multicolumn{5}{|c|}{ Date:11/16/15Time:12:04 } \\
\hline \multicolumn{5}{|c|}{ Sample(adjusted):19812013 } \\
\hline \multicolumn{5}{|c|}{ Included observations: 33 after adjustments } \\
\hline Variable & Coefficient & Std. Error & t-Statistic & Prob. \\
\hline $\mathrm{D}(\mathrm{CBC})$ & -1.425907 & 5.727303 & -0.248966 & 0.9958 \\
\hline $\mathrm{D}(\mathrm{NOE})$ & 0.010313 & 0.022667 & 0.454992 & 0.6526 \\
\hline $\mathrm{D}(\mathrm{CBB})$ & -1.018060 & 0.268935 & -3.785518 & 0.0007 \\
\hline $\mathrm{D}(\mathrm{EXR})$ & -1.462626 & 0.759252 & 1.926404 & 0.0043 \\
\hline $\operatorname{ECM}(-1)$ & -0.234417 & 0.111544 & -2.101567 & 0.0447 \\
\hline R-squared & 0.8504041 & Mean dependent var & & 20.601822 \\
\hline Adjusted R-squared & 0.8297702 & S.D. dependent var & & 45.263233 \\
\hline S.E. of regression & 41.110504 & Akaike info criterion & & 10.409135 \\
\hline Sum squared resid & 47322.053 & Schwarz criterion & & 10.635878 \\
\hline Log likelihood & -166.7507 & Hannan-Quinn criter. & & 10.485426 \\
\hline Durbin-Wats stat & 1.6155313 & & & \\
\hline F-statistic & 41.213925 & & & \\
\hline Prob (F-statistic) & 0.0000000 & & & \\
\hline
\end{tabular}

Source: Author's Computation using E-views 7.0

From the Error Correction Model estimates presented in (Table 4) above, revealed that the independent variables jointly account for approximately 82.98 percentage changes in Return on Investment, dependent variable as represented by the coefficient of determination (R-squared). The DurbinWatson statistics (1.62) is within the acceptable range and shows no presence of autocorrelation. The Error Correction Mechanism or model (ECM) is of the normal negative sign furthermore measurably noteworthy at 5\% level of significant. The outright estimation of the coefficient of the error correction term demonstrates that about $23.44 \%$ of the disequilibrium in Return on Investment is balanced by short run alteration in every year. The related F-Statistic estimation of 41.21392 is critical at 0.05 level of significant, and it affirms the decency of fit.

Looking at the estimation results, it is observed that two of the independent variables, Cross Boarder Banking Claim to Total Banks Assets and Exchange Rate of Nigeria's Naira to
America's Dollar are statistically significant in explaining variability in Corporate performance of the deposit money banks captured by their Return on Investment at 5\% level of significance. The probability coefficient of Cross Boarder Banking Claim to Total Banks Assets is 0.0007 and that of Exchange Rate is 0.0043 , both of which are less than 0.05 level of significance and indicating a significant relationship with the Dependent variable, Return on Investment. However, Credit across countries to Total Deposit Money Banks Assets and Non-oil Export to Total Deposit Money Banks Assets, according to the result is not statistically significant in explaining variation in Return on Investment at 5 percent level of significance. The probability estimate of Credit across countries to Total Deposit Money Banks Assets is (0.9958) and that of Non-oil Export to Total Deposit Money Banks Assets is 0.6526 both of which are greater than 0.05 our preferred level of significance, thus indicating an insignificant relationship with the dependent variable. 


\subsection{Test of Hypotheses}

The hypothetical tables below shows the calculated and critical t-statistics, probability value, degree of freedom, level of significance, as well as remark.

$\mathrm{H}_{01}$ : There is no statistically significant relationship between credit growth across countries and Return on Investment of Deposit Money Banks in Nigeria.

$\begin{array}{ll}\text { Calculated t-statistics } & -0.248966 \\ \text { Critical t-statistics } & 2.660 \\ \text { Probability Value } & 0.9958 \\ \text { Degree of Freedom } & 32 \\ \text { Level of Significance } & 5 \% \text { (2-tailed) } \\ \text { Remark } & \text { Accept null hypotheses }\end{array}$

$\mathrm{H}_{02}$ : There is no statistically significant relationship between growth of international trade and the Return on Investment of deposit money banks.

$\begin{array}{ll}\text { Calculated t-statistics } & 0.454992 \\ \text { Critical t-statistics } & 2.660 \\ \text { Probability Value } & 0.6526 \\ \text { Degree of Freedom } & 32 \\ \text { Level of Significance } & 5 \% \text { (2-tailed) } \\ \text { Remark } & \text { Accept null hypotheses }\end{array}$

$\mathrm{H}_{03}$ : There is no statistically significant relationship between cross boarder banking claims and the Return on Investment of Deposit money banks in Nigeria.

$\begin{array}{ll}\text { Calculated T-statistics } & -3.78552 \\ \text { Critical T-statistics } & 2.660 \\ \text { Probability Value } & 0.0007 \\ \text { Degree of Freedom } & 32 \\ \text { Level of Significance } & 5 \%(2 \text {-tailed) } \\ \text { Remark } & \text { Accept alternative Hypotheses }\end{array}$

$\mathrm{H}_{04}$ : There is no statistically significant relationship between the exchange rate and Return on Investment of money banks in Nigeria.

$\begin{array}{ll}\text { Calculated t-statistics } & 1.926404 \\ \text { Critical t-statistics } & 2.660 \\ \text { Probability Value } & 0.0043 \\ \text { Degree of Freedom } & 32 \\ \text { Level of Significance } & 5 \% \text { (2-tailed) } \\ \text { Remark } & \text { Accept alternative hypotheses }\end{array}$

\section{Discussion of Findings}

The opinion that the global monetary arena can affect the performance of the financial market with the emerging economies can be traced to the global monetary crises of the 1970 's that led to the devaluation of Nigerian currency. Onoh (2007) noted that the global monetary instability in the time led to various exchange rate policies used by Nigerian economy to leverage effect of the crises on Nigerian financial market and to the global financial crises of the 2007/2008 which led to the crash of the Nigerian capital market which spill to the banking sector. This study is aggravated to observe the relationship between the global financial liquidity and its effect on the performance of Nigerian banking sector as most Nigerian banks has gone beyond national boarders such as First Bank United Kingdom, Union Bank United Kingdom. It is assumed that the expansion of Nigerian banking system across boarder will enhance credit inflow, facilitate international trade, promote cross boarder banking claim and leverage Nigerian exchange rate challenges which are prerequisite for better performance of the Nigerian banking industry.

Findings from the regression results reveal that on the aggregate the independent variables modeled in the study have significant influence on the performance of the deposit money banks in Nigeria. The findings confirm the apriori expectation of the results and the policies that facilitate the expansion of Nigerian banks abroad. It also indicates that the management is effective in managing the global liquidity crises over the period of this study. Result of this study confirm the findings of Beltratti and Stulz (2009) whose study found that great banks that has adequate deposit financing at the end will exhibits significant advanced returns during crisis, Ree (2011) found that as low as financial integration, the shock of the crisis on banks, mainly the major banks, were significant. The shock was majority conspicuous through loan to a cross the border financial support nexus. According to Khamis (2010) banks were fewer pretentious by the crises than their partners in developed economies, regardless of a progression of shocks, there has been on systemic break down and the effect on bank productivity has been direct as such, but contrary to the findings of Samad (2004), Dietrich and Wanzenried (2011), Ashamu and Abiola (2012), Sangeetha (2012), Anouze (2007), Shafique, Faheem and Abdullah (2008), Al-Nessor (2008), Almeida etal. (2009), Berger and Christa(2010), on the negative effect of the global financial crises on the performance of cross boarder banking. However, the insignificant effect the insignificant effect of the variables can be traced to monetary policy shocks, international liquidity crises and the inability of the bank management to effectively manage the global liquidity transactions.

Therefore, it is concluded that the relation between capital flows across boarder and the financial sector performance of the emerging economies can be reviewed from two perspectives; a stable global liquidity is anticipated to have positive effect on performance of the financial market while the global financial crises can have a negative effect on the financial sector performance. The study concludes that:

There is a positive but insignificant relations exist between growth of cross boarder credit across countries and the performance of Nigerian deposit money banks.

It also shows positive but insignificant relations between growth of international trade proxy by non-oil export and the performance of Nigerian deposit money banks.

It shows that a positive but statistically insignificant relations between cross boarder banking claims and the performance of deposit money banks. 
There is a positive and statistically significant relations exist between exchange rate and the performance of deposit money banks in Nigeria.

From the findings, the following recommendations are made:

There is need for the deposit money banks management to strengthen their international financial transactions management scope as the indicators studied largely exhibit strong influence on the performance of deposit money banks. There should be well defined structure of investment in Nigeria's international financial transactions position to enhance the performance of deposit money banks.

Monetary authority should ensure that favorable Domestic policy is put in place to hedge against the negative effect on foreign exchange. Diversification of the economy enhances the international trade position of the country thereby strengthening the value of the local currency against foreign currencies.

Nigerian foreign assets and bank investment abroad should be invested in profitable global financial instruments to enhance performance of deposit money banks in Nigeria.

\section{References}

[1] Abebefe, H. A. (1995),“The structure of Nigeria's external trade", Bullion, 19 (4).

[2] Almeida, H., Campello, M., Larajerria, B., and Weisbenner, (2009). Corporate debt maturity and the real effect of the 2007 credit crises. Unpublihed working paper, University of Illcions.

[3] AlNessor, M., (2008). The impact of financial crises on capital markets, trade and economics Arabic. Symposium Global Financial Crises and its implications for financial markets and the Arab Economy." American Jornal 14 (8), 128-134.

[4] Anouze, A. L. (2007). "The Efficiency of banks performance in Gulf Region before, during and after crisis (Financial and Political)"8th Global Conference on Islamic Economics and Finance.

[5] Ashamu, S. O and Abiola, J., (2012). "The impact of Global Financial Crises on the banking sector in Nigeria." British Journal of Arts and social sciences, Vol 4 (2), 314-329.

[6] Basel Committee on Banking Supervision (2009). "Global frame work for liquidity risk measurement, standards and monitoring," consultative document.

[7] Basel Committee on Banking Supervision (BCBS) (2010c). "Base 1III: Global framework for liquidity risk measurement, standards and monitoring,"http://bis.org/publ/bcbs188.pdf.

[8] Beltratti, A., Stulz, R., (2009). Why did some banks perform better during the credit crisis? Across-country study of the impact of governance and regulation, ECG I's Finance Working Paper No. 254/2009.

[9] Berger, A. N and Christa, H. S. (2010) Bank liquidity Creation, Monetary Capel, J. J., 2009, 'How does cross-border collateral affect a country's central bank and prudential supervisor, "DNB Occasional Studies, Vol. 7, No. 1, http://www.dnb.nl/binaries/Occasional\%20Studies $\% 20 \mathrm{Vol} \% 2$
07 tcm46-220381.pdf.

[10] Brown, M. R. de Haas, (2012). "Global Bank, Global Shock Transmission and Economic Growth: Evidence from the Crisis," IMF Economic Review 59 (1), 41-76.

[11] Cornett, M., McNutt, J. and Tehranian, H., (2010). "The financial crisis, internal corporate governance, and the performance of publicly-traded U.S. bank holding companies,"unpublished working paper, Bost on College.

[12] Demirgüç-Kunt, A. and Huizinga, H. (2001). Financial Structure and Bank Profitability. In Financial Structure and Economic Growth: A Cross-Country Comparison of Banks, Markets, and Development, Cambridge, MA: MIT Press. Retrieved on March 10, 2005 from http://www.econ.world bank.org/docs/1185.pdf.

[13] Dickey, D., \& Fuller, W., (1981)."Likelihood ratio statistics for autoregressive time series with a unit root."Econometrical 7 (49), 1057-1072.

[14] Dietrich, A., Wanzenried, G., (2011). "Determinants of bank profitability before and during the crisis: Evidence from Switzerland," J. Int. Finance. MarketsInst. Money, doi:10.1016/j.intfin.2010.11.002.

[15] Fayez, J. S., and Alnajar, J., (2009). The Global Financial crises and its impact on the financial companies listed in Amman Stock Exchange.

[16] Global Monetary Fund (IMF), (2010). 'Global Financial Stability Review', http://www.imf.org/External/Pubs/FT/GFSR/2010/02/pdf/text. pdf ISSN: 2046-9578, Vol.4No.2(2012).

[17] Halkos, G., Simonson, D., (2004). Efficiency measurement of Greek Commercial banks with the use of financial ratios. A data envelope analysis approach. Management Accounting Research 15 (2), 201-224.

[18] Halland, O. and Vierra, R. (2005). "Economic liberalization, and exchange management and foreign capital."IMF working paper.

[19] Jiwan, W. (2011). Global Liquidity, Cross Boarder Capital and Economic Growth in the Developing Countries. Global Journal of Economics and Finance, 5 (21), 185-219.

[20] Khamis. M (2010). "The Impact of the Global Financial Crisis on the GCC Region: Lessons and Reform Priorities, Round table on Effective and Efficient Financial Regulation in the MENA Region,” December 6-7, 2010 Doha, Qatar, Global Monetary Fund.

[21] Kityota, H., (2009). Confronting global financial crises. Bank efficient, profitability and banking system in Africa. A paper prepared for the African economic conference on fostering development of financial and economic crisis. Addis Ababa.

[22] Lacewell, S. K., (2003). Do efficiency institutions score well using ratio analysis. An examination of Commercial banks in the 1990s. Journal of commercial banking and finance 2, (5) 17-33.

[23] McClean, H., and Shrestha, W. (2009). Global Financial Crisis and Economic Growth of Developing Nations. American Journal of economics. 7 (30), 155-195.

[24] Onoh, J. K., (2007). Dimensions of Nigerian's Monetary and Fiscal Policy. Astra Meridien, Aba, Enugu, Lagos. 
[25] Onwe, O. J. (2013), "Trade balances and economic progress in Nigeria: Analysis of the oil and non-oil subsectors", International Journal of Business and Social Science, 4 (8).

[26] Osuntogun, A., Oramah, B. O. and Edordu, C. C (1997), "Potentials for diversifying Nigeria's non-oil exports to nontraditional markets", AERC Research Paper, No. 68.

[27] Ree, J. K., (2011). Impact of the global crisis on the banking sector soundness in Asian Low-income countries. IMF working paper.

[28] Sangeetha. J, (2012) Financial Crisis and Omani Commercial Banks: A Performance Review, European Journal of Business and Management, www.iiste.org ISSN2222-1905 (Paper) ISSN2222-2839 (Online) Vol 4, No. 8, 2012.

[29] Seiford, L. M., \& Zhu, J., (1999). Profitability and marketability of the top 55 U.S Commercial banks. Management services, 45 (9), 1270-1288.

[30] Shafique. A, Faheem. M. and Abdullah. J, (2012). Impact of Global Financial Crises on the Islamic Banking System.
Arabian Journal of Business and Management Review (OMAN Chapter) Vol. 1, No. 9; April 2012.

[31] Samad, A., (2004). Bahraim Commercial banks' performance during 1994-2001. Credit and financial Management Review $10(1), 33-40$.

[32] Tarawneh, M. (2006). A Comparison of Financial Performance in the Banking Sector: Some Evidence from Omani Commercial Banks". Global Research Journal of Finance and Economics 3, pp 103-112.

[33] Webb, R. M., (2003). Levels of Efficiency in UK retail banks: ADEA window analysis. Global Journal of the economics of business 10 (3), 305-322.

[34] Xiao, Y., (2009). French banks Amid the global financial crises. IMF working paper. WP/09/201.

[35] Yeh, Q., J., (1999). The application of data envelopment analysis in conjunction with financial ratios for bank performance evaluation. Journal of the operational research society.47, 980-988. 